\title{
Effect of COVID-19 on Medical Education and Examination: A Cross-Sectional Survey across Medical Colleges of Pakistan
}

\author{
Abdul Rafay, Halaila-tul-Hiba, Manahil Jamil, Ashhar Arshad, Azhar Hussain, Awais A. Malik, \\ Muhammad F. Afzal
}

\section{ABSTRACT}

Background: COVID-19 outbreak was first reported in the Wuhan city in 2019 , causing the whole world to undergo a period of lockdown to curtail the disease. This affected education and examination of medical students across the world including Pakistan.

Objective: To know the impact of COVID-19 on the medical education and future of medical examination, from medical students' perspective.

Methods: An online qualitative survey was conducted among the medical students of different medical colleges of Pakistan from $2^{\text {th }}$ October 2021 to $15^{\text {th }}$ November 2021. Google forms were used to collect data. Informed consent was obtained at the start of the survey. SPSS version 22 was used for data analysis.

Results: Our study had a response rate of $99.7 \%$ with 4548 respondents, ranging from the first year to final year MBBS. The highest number of respondents were from $1^{\text {st }}$-year MBBS and accounted for $25.4 \%(n=1153$ responses). $93 \%(n=4254)$ of the respondents agreed that lockdown had impacted their education, $85.1 \%(n=3870)$ were having online classes and only $9.6 \%(n=436)$ were satisfied with online education. $65 \%(n=2998)$ considered online education to be an ineffective teaching method. Only $25 \%$ of the respondents $(n=1137)$ wanted to be examined online whereas $34.5 \%(n=1571)$ were of the view that online viva was an ineffective method of examination. $41 \%(n=1897)$ of the respondents considered that students should be promoted without examination during the COVID-19 pandemic and $41.5 \%(n=1886)$ thought that students who had passed the written exam should be promoted without viva. $46 \%(n=2117)$ favored the rational method of exam.

Conclusions: Our data showed that the majority of students having online classes were not satisfied with this mode of education due to financial constraints, connectivity issues and quality of lectures and these problems need to be resolved.

Keywords: COVID-19, examination, online medical education.

Submitted: January 23, 2022

Published: February 15, 2022

ISSN: 2593-8339

DOI: $10.24018 /$ ejmed.2022.4.1.1218

A. Rafay*

Lahore General Hospital, Lahore, Pakistan.

(e-mail:

dr.abdulrafay1013@gmail.com)

H.-t.-Hiba

Lahore General Hospital, Lahore, Pakistan.

M. Jamil

Holy Family Hospital, Rawalpindi, Pakistan.

A. Arshad

Mayo Hospital, Lahore, Pakistan.

A Hussain

Ameer-ud-din Medical College,

Lahore, Pakistan.

A. A. Malik

Lahore General Hospital, Lahore,

Pakistan.

M. F. Afzal

Lahore General Hospital, Lahore,

Pakistan.

*Corresponding Author

\section{INTRODUCTION}

COVID-19 outbreak, the modern world's biggest fear was formerly known as SARS Cov-2 (pneumonia of unknown etiology). It was first reported in the Wuhan city, Hubei

Province of Mainland China in 2019 [1], [2]. COVID-19 has caused greater damage to the human race since the 2 nd World war affecting 79,41,791 people across the globe out of which 434,796 people have died as of $16^{\text {th }}$ June 2020 [3]. World health organization (WHO) called Covid-19 a global pandemic of great concern on $11^{\text {th }}$ March [4], [5].

As a result of this disaster, the whole world underwent a period of lockdown in order to curtail the disease. Pakistan reported its first case on $26^{\text {th }} \mathrm{Feb} 2020$ [6]. The whole country went under a lockdown phase on $15^{\text {th }}$ March 2020 in which all kinds of activities were suspended, and schools, colleges, and universities were closed.

This closure and suspension also affected the students of medical institutions across the world including Pakistan as all academic activities including examinations were suspended [7]. This subjected medical students to psychological and emotional trauma [8]. This lockdown seriously affected the traditional method of medical education and the world moved to the concept of digital learning in order to continue educational activities in this time of crisis through the use of technology [9].

Moreover, in order to facilitate the graduation of students, the world has opted for different methods of promotion of students. Some countries allowed students to get promoted in the time of crisis to help their health care system while others opted for alternative methods of assessment to help students get their degrees [10], [11].

This study was conducted across the medical institutions of two provinces in Pakistan; Punjab and Azad Jammu Kashmir to know the students' perspective on the impact of COVID-19 on Medical Online education, supplementary examination, and the future of annual examination. 


\section{MAterials AND MethodS}

This study was conducted among the students of all the medical institutions across the Punjab and Azad Jammu Kashmir. The data was collected from $20^{\text {th }}$ October 2021 till $15^{\text {th }}$ November 2021. The informed consent was obtained from students at the start of an online survey through Google forms. This is a qualitative online survey-based crosssectional study in which 4548 students participated from different institutions of all five years of M.B.B.S. We divided our survey into three categories.

The $1^{\text {st }}$ part of the survey, asked about the effectiveness and impact of COVID-19 on online Education. The $2^{\text {nd }}$ part covered the mode of supplementary examination. $3^{\text {rd }}$ part of the survey inquired about the future of the annual examination.

A google form was used for the survey and questionnaire. SPSS windows version 22 was used to analyze the data. Pvalue $<0.05$ was considered statically significant and the chisquare test was applied to find any significance among different qualitative variables of the study.

\section{RESULtS}

Out of 4548 Medical students who participated in the survey, $1153(25.4 \%)$ students belonged to $1^{\text {st }}$ year, 904 $(19.9 \%)$ were from $2^{\text {nd }}$ year, $793(17.4 \%)$ students belonged to $3^{\text {rd }}$ year, $753(16.6 \%)$ students were from $4^{\text {th }}$ year and 931 $(20.5 \%)$ students were from final year.

Among 4548, 4254 (93.5\%) students thought that lockdown had affected their education, $129(2.8 \%)$ thought lockdown did not affect their education, 151 (3.3\%) students were not sure about this question, and $14(0.3 \%)$ declined to answer.

Among those 4548 students, 3870 (85.1\%) students were having online classes and $664(14.6 \%)$ students were not having online classes. On the question of satisfaction with the online method of education, among 4548 students, 3387 $(74.5 \%)$ students were not satisfied, a total of $436(9.6 \%)$ students were satisfied with online classes while $711(15.6 \%)$ were not sure.

About the effectiveness of this methodology till the end of the pandemic, out of 4548 students, 2998 (65.9\%) students did not find this methodology effective till the end of the pandemic, $681(15 \%)$ thought that this could be used while the rest of $855(18.8 \%)$ thought that it could be used but not sure about it.

On the mode of annual examination, among these 4548 students, $2117(46.5 \%)$ students were in favor of the traditional method of annual examination given the condition does not improve over next few months, 1610 (35.4\%) wanted to take an only online written examination, 807 $(17.7 \%)$ were in favor of online home-based proctor examination with real-time technology including online viva.

On the issue of online viva among 4548 students, $1571(34.5 \%)$ students do not think online viva can replace physical examination for passing a professional examination, $582(12.8 \%)$ think that this can be applied under special circumstances, and 330 (7.3\%) were uncertain, while 2065 (45.4\%) refused to answer.

On the timings of the annual examination, among 4548 students, $3897(85.7 \%)$ students think that the annual examination should not take place on time. $416(9.1 \%)$ students were in favor of having the examination on time, 221 (4.9\%) students were not sure about it.

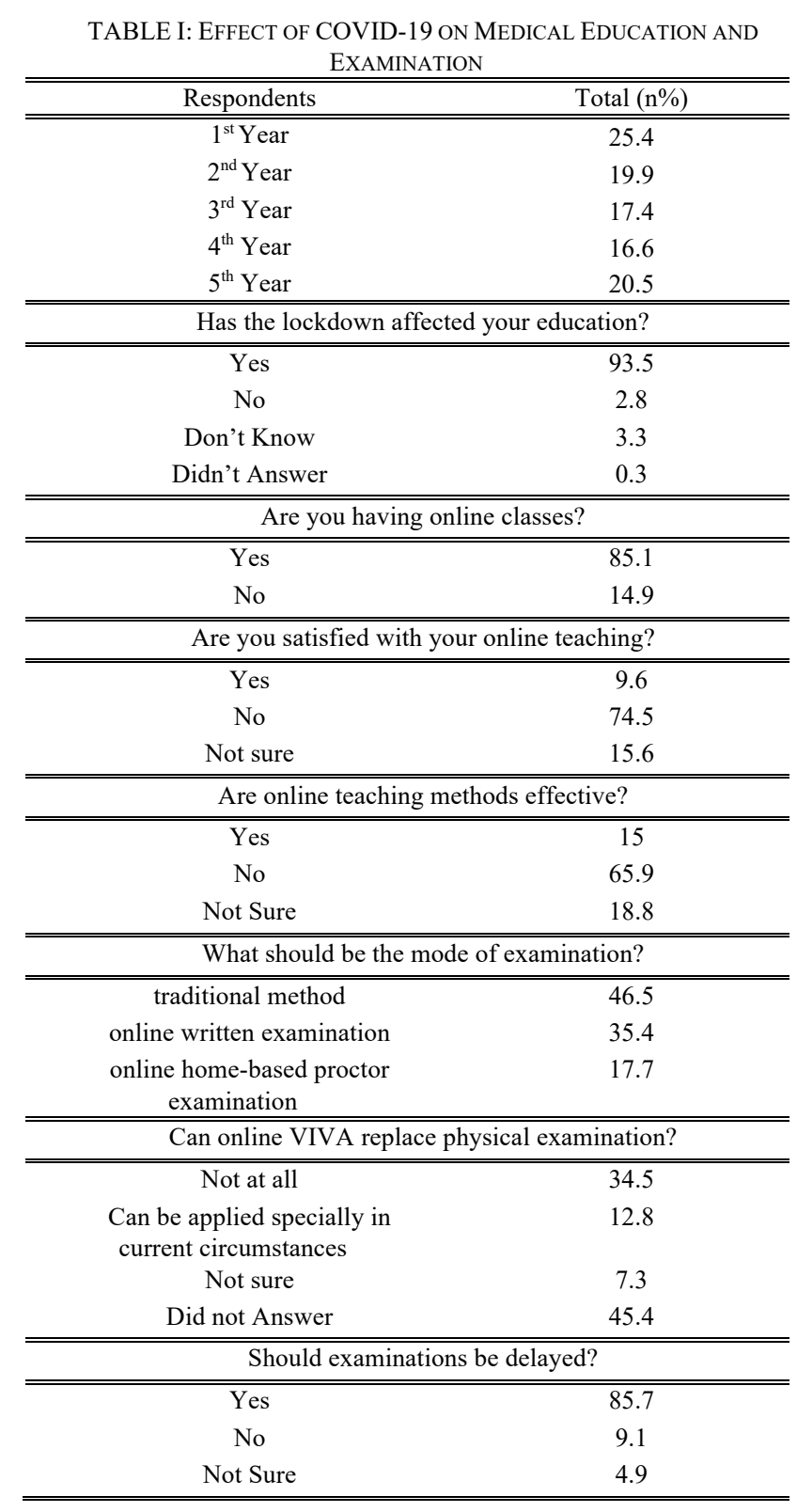

\section{DISCUSSION}

We are currently in a state of uncertainty because we are facing a pandemic, COVID-19. Experts are still trying to find its variations and pathogenesis which has caused the world a great loss in every manner [12]. Millions got infected and hundreds and thousands lost their lives. World and WHO including several websites which are continually updating their figures and with passing timing the situation is becoming grimmer, and we are hoping for some help from the Divine Power and the potential vaccination and treatment [13], [14].

This research was conducted as an online survey-based cross-sectional study to know the perspective of medical students on the impact of the halt of academic activities, online classes, and the future of annual examinations.

With the closure of medical institutions in mid of March 
2020 in Pakistan, educational activities were suspended for some time but later on medical colleges of Pakistan like the rest of the world started taking online classes to continually provide medical education to students [15], [16]. To know the effectiveness of these classes, results from our study show that majority of students who were having online classes were highly unsatisfied with this mode of education and they don't think that this method of education was effective till the end of the pandemic because the majority of students were having internet connectivity issues alongside financial constraints to buy laptops, and smartphones for this purpose but some find this method of education suitable for prospects [17]. Our results on online classes were in concordance with the results from other countries [18].

The majority of the students want to get promoted based on their previous results on an alternative criterion without examination, while if the promotion without examination is out of the question as decided by the home country medical governing body, then the alternative methods of examination should be opted, but they should be mentally relieved of this emotional dilemma of examination [19]. The results from our study support the response of European countries that promoted and fast-tracked their medical students to help curb the situation [20], [21].

On the future of annual examination, our results show that the majority of students want a delay in the annual examination due to loss of their academic activities especially the clinical rotation and practical examination which was severely disturbed due to the pandemic [22], [23]. Our results also show that if after delay; the situation of pandemic does not get better, they may become ready to take online examinations as an alternative to save their academic year from going waste.

\section{CONCLUSION}

Results from our study show that online classes are not popular among medical students. Similarly, students were split into whether we can still hold examinations traditionally and whether online examinations can be a replacement for real-time examinations. We believe that there are a lot of apprehensions and misconceptions among students with regards to online teaching and examination systems and these should be addressed as soon as possible because we believe that given the current situation of the pandemic there is no way out of these newer methods of teaching and examination. After all, the pandemic is still a long way to go.

\section{CONFLICTS OF INTEREST}

In compliance with the ICJME uniform disclosure form, all authors declare the following:

A. Payment/services info: All authors have declared that no financial support was received from any organization for the submitted work.

B. Financial relationships: All authors have declared that they need no financial relationships at the present or within the previous three years with any organizations which may have an interest within the submitted work.

C. Other relationships: All authors have declared that there are not any other relationships or activities that would appear to possess influenced the submitted work.

\section{REFERENCES}

[1] Bogoch II, Watts A, Thomas-Bachli A, Huber C, Kraemer MUG, Khan K. Pneumonia of unknown aetiology in Wuhan, China: potential for international spread via commercial air travel. J Travel Med. 2020; 27(2): taaa008.

[2] Lu H, Stratton CW, Tang YW. Outbreak of pneumonia of unknown etiology in Wuhan, China: The mystery and the miracle. J Med Virol. 2020; 92(4): 401-402.

[3] Coronavirus disease (COVID-19) Situation Report - 148 Data [Internet] [cited on 2020 June 16] Available from: https://www.who.int/docs/default-source/coronaviruse/situationreports/20200616-covid-19-sitrep-148-draft.pdf?sfvrsn=9b2015e9_2

[4] Coronavirus disease 2019 (COVID-19) Situation Report - 51 [Internet] [cited on 2020 March 11] Available from: https://www.who.int/docs/default-source/coronaviruse/situationreports/20200311-sitrep-51-covid-19.pdf?sfvrsn=1ba62e57_10

[5] World health organization (WHO). [Internet] Available from: https:/www.who.int/emergencies/diseases/novel-coronavirus-2019

[6] Waris A, Atta UK, Ali M, Asmat A, Baset A. COVID-19 outbreak: current scenario of Pakistan. New Microbes New Infect. 2020; 35: 100681.

[7] Delays, miscommunications add even more stress to USMLE Step exams. [Internet] [cited on 2020 June 2] Available from: https://www.ama-assn.org/residents-students/usmle/delaysmiscommunications-add-even-more-stress-usmle-step-exams

[8] Sahu P. Closure of Universities Due to Coronavirus Disease 2019 (COVID-19): Impact on Education and Mental Health of Students and Academic Staff. Cureus. 2020; 12(4): e7541.

[9] Almarzooq ZI, Lopes M, Kochar A. Virtual Learning During the COVID-19 Pandemic: A Disruptive Technology in Graduate Medical Education. J Am Coll Cardiol. 2020; 75(20): 2635-2638.

[10] Franchi T. The Impact of the Covid-19 Pandemic on Current Anatomy Education and Future Careers: A Student's Perspective. Anat Sci Educ. 2020; 13(3): 312-315.

[11] Sabzwari S. Rethinking Assessment in Medical Education in the time of COVID-19. MedEdPublish. 2020; 9(1): 80.

[12] Liu Z, Bing ZX, Zhi XZ. Epidemiology Working Group for NCIP Epidemic Response, Chinese Center for Disease Control and Prevention. The epidemiological characteristics of an outbreak of. 2020; 41(2): 145-151.

[13] Kaup S, Jain R, Shivalli S, Pandey S, Kaup S. Sustaining academics during COVID-19 pandemic: The role of online teaching-learning. Indian J Ophthalmol. 2020; 68(6): 1220-1221.

[14] Coronavirus 2019-nCoV, CSSE. Coronavirus 2019-nCoV Global Cases by Johns Hopkins CSSE. [Internet] Available from: https:/gisanddata.maps.arcgis.com/apps/opsdashboard/index.html\#/b da7594740fd40299423467b48e9ecf6)

[15] Clark J. Fear of SARS thwarts medical education in Toronto. BMJ. 2003; 326(7393): 784.

[16] Lim EC, Oh VM, Koh DR, Seet RC. The Challenges of "Continuing Medical Education" in a Pandemic Era. Annals of the Academy of Medicine Singapore. 2009; 38; 724-726.

[17] Patil NG, Chan Y, Yan H. SARS and its effect on medical education in Hong Kong. Med Educ. 2003; 37(12): 1127-8.

[18] Strengths and Weaknesses of Online Learning. University of Illinois Springfield. [Internet] Available from: https://www.uis.edu/ion/resources/tutorials/online-educationoverview/strengths-and-weaknesses/

[19] Nation News. [Internet] Available from: https://nation.com.pk/19May-2020/medical-students-won-t-be-promoted-without-exams

[20] Final-year medical students graduate early to fight Covid-19. The Guardian. [Internet] Available from: https:/www.theguardian.com/world/2020/mar/15/uk-medicalschools-urged-to-fast-track-final-year-students-to-help-fightcoronavirus

[21] Thousands of medical students are being fast-tracked into doctors to help fight the coronavirus. The CNN. [Internet] Available from: https://edition.cnn.com/2020/03/19/europe/medical-studentscoronavirus-intl/index.html

[22] Poulton T, Balasubramaniam C. Virtual patients: a year of change. Med Teach. 2011; 33(11): 933-7.

[23] Berman NB, Durning SJ, Fischer MR, Huwendiek S, Triola MM. The Role for Virtual Patients in the Future of Medical Education. Acad Med. 2016; 91(9): 1217-22. 